\title{
CAPACITY, POTENTIAL, AND ABILITY: INTEGRATING DIFFERENT APPROACHES TO STUDYING ANIMAL VS HUMAN CREATIVE PROCESSES
}

\author{
James C. Kaufman \\ Neag School of Education \\ University of Connecticut \\ 2131 Hillside Road, Storrs, CT 06269-3007, USA \\ Allison B. Kaufman \\ University of Connecticut, Avery Point \\ 1084 Shennecossett Rd., Groton, CT 06340, USA
}

For all of the differences between studying animal and human creativity and innovation, there are enough similarities that we can gain insight by integrating both perspectives. Both research approaches focus on creative ability, but animal studies favor the concept of creative capacity whereas human scholars prefer the idea of creative potential. We explore here the implications of these differences and what each field can learn from the other.

Key words: creativity, animal creativity, creative potential, creative genius

The difference between creative capacity and potential may seem to be one of semantics. Yet exploring why studies human creativity tend to focus on the concept of "potential" and why animal creativity tends to emphasize "capacity" sheds light on how the two areas of study can inform each other. Both concepts can work together to give insight into how capacity and potential can become ability.

In the study of human creativity, a core concept is the distinction between little-c (everyday creativity) and Big-C (eminent creativity). Many of the legends in the field focused on little-c, which was sometimes called creative potential [55]. The little c/Big-C split has more recently been transformed into the Four C Model [36], which traces the progression of a creative life from mini-c (personal creativity) to little-c to Pro-c (expertlevel creativity) to Big-C. Mini-c specifically includes insights or thoughts that are personally meaningful to the creator but which may not seem to be creative to the outside world [4]; the entire category is explicitly focused on creative potential. Someone could be mini-c creative without ever putting a thought on paper or even articulating an idea to another person.

A large percentage of creativity research is aimed at turning creative potential into ability [15]. Whether in the form of teacher advice [5] or workplace guidelines [2], a great deal of energy is spent trying to move humans from showing creative potential to expressing creative ability. The question of human creative capacity is rarely addressed. Some theories outline the basic requirements needed to be creative [3], such as some level of intelligence and motivation and an environment that at least tolerates creativity; these might be considered to be the minimum capacity needed for creativity. Further, many discussions 
of Big-C touch on creators who represent the best or epitome of greatness in a given field $[19 ; 54]$. Yet in general, the idea of creative capacity is not one that inspires much discussion.

In contrast, capacity is an important component of non-human animal (henceforth "animal") research. The term typically refers to a creature's inherent physiology and genetic makeup. As such, capacity can encompass a working neural system, the ability to create and use energy, genes which code for the proper proteins, and motor abilities. Observing an animal in its natural habitat may yield evidence of its abilities, but not its capacities [42; 56]. Although an animal may stretch itself to its full capacity under extreme duress in order to survive, it is not adaptive for an animal to push itself to such intensity on a daily basis. Natural selection favors the creatures who do "good enough" - ones which do better than those who are competing for the same resources, but not so much better as to waste valuable resources [22]. If traditional means of obtaining the basic necessities are working, there is no benefit to finding new ways to hunt or forage. One might make the analogy to humans who are at the lower end of Maslow's [43] hierarchy of needs. If one's focus is on obtaining adequate food and shelter, creativity for its own sake may seem like a luxury. Creativity can be seen more as a problem-solving tool to find a better path to survive [34].

Nonetheless, there are some animals who express creativity in the process of obtaining their basic needs. The Japanese Macaque nicknamed Imo [38] learned to wash her potatoes in a nearby stream to rid them of sand - instead of wiping off the grit, as the others did. Imo's behavior soon spread to the rest of the group via observational learning, essentially creating a cultural practice among that group. Other animals adopted Imo's creative behavior. It is obviously impossible to determine if her peers viewed her as creative, but it is reasonable to posit that they recognized the utility of her novel behavior. In fact, even their recognition of Imo's solution being different could qualify as a lower-level act of creativity [33; 37]. By the Four C model Imo would easily qualify as little-c. At a subsequent time, when researchers presented her rice mixed with sand (in an unrelated experiment), Imo threw handfuls of the mixture in the water [38] (Kawai, 1965). Her actions caused the rice to float and the sand to sink, thereby cleaning her food faster and enabling an easy snack. Given Imo's repeated innovations, she could be argued to be Pro-c [36; 37].

What was Imo's motivation? If she were a person, we could simply ask her. We know that people create for many reasons - tangible rewards, personal passion, or altruistic principles [16]. Intrinsic motivation is often thought to best promote creativity [25], in part because it can free people from worrying about situational contexts [1]. The added attentional resources can then allow people to better focus on a specific task. Without the ability to obtain a deeper understanding of a penguin's purpose, however, it is hard to determine if they are ever creative for enjoyment's sake.

Consider play; in humans, imaginative play is an important determinant of future creativity [51] and yet still part of childhood development [50] and adult leisure [23]. In animals, it is more likely to have a specific goal, such as social rehearsal, the reinforcement of group status, or the refinement of predatory skills [8]. There are behavioral interactions that do not fit traditional categories and might be done to amuse [8], but even these are not always clear. 
From a strictly biological perspective the reasons to be creative are limited. Imo's resources might have been low (and a new foraging technique would have led to additional food). Maybe Imo was trying to impress a mate. However, neither of these things seem likely. All we know is that her basic needs appeared to have been met, yet she still chose to solve a puzzle.

Creatures who innovate in the wild often come from subordinate members of a group and subsequently have more time on their hands [49]. They are not defending territory or mates, and they have more to gain if their efforts are successful (such as the very lowly ranked chimp who used metal trashcan lids in a dominance display), and less to lose if they fail [41].

In the lab, the situation changes. Competition for everyday needs is gone; everyone has sufficient food, water, and shelter. Resources can be abundant. Under these settings, cognitive experiments can encourage an animal to use its full capacity. Again, to follow the Maslow [43] analogy with humans, the lab might represent a setting in which the basic levels of needs have been reached, allowing questions of esteem and actualization to be addressed (perhaps via creative expression).

The key potential-capacity discrepancy emerges when an animal is studied in a lab who turns out to have extraordinary abilities. Such animals can become the sole focus of an investigation. In this type of "power study" [56], as it is sometimes called, it is difficult to generalize behavior or even the potential for behavior to others in the species. The animals who warrant such extensive investigation are producing behavior so far above the average standard that if they were human, they would be labeled brilliant.

However, it is not unreasonable to suggest that all members of the same species share the same capacity for such behavior, even if it is unlikely or even impossible for them all to reach the same potential, even accounting for comparable environmental stimulation [42]. This concept in research dates back at least 35 years:

A power study, because it depends on the behavior of one or a few individuals to provide evidence for the existence of a given conceptual ability, does not permit inter- or intra-species comparisons. Yet, tabulating or statistically comparing the relative success and failures of multi-individual samples of animals would not identify the intellectual capacity of a species satisfactorily and, in fact, is often quite misleading. If one individual can consistently and reliably demonstrate a given level of concept attainment, the performance is proof that this level is within the capacity of the species. Many failures by other individuals cannot invalidate this conclusion; they may identify the typical performance of a species, but not the conceptual ability of the species [56, pp. 135-136].

Consider that every parrot has the same neural structure as Alex, the African Grey parrot (Psittacus erithacus) who could sum numbers zero to six, used and created labels for objects, and understood the concepts of same and different [45-47]? Or that every bonobo (Pan paniscus) metabolizes glucose in the same way as Kanzi, the bonobo who acquired language without direct training [53]. The difference is that the African rainforest doesn't stretch parrots or primates to their highest potential for cognitive reasoning or language development. The laboratory can offer this type of environment, and many researchers thus argue that these individual differences in ability are due to the specific circumstances [42; 44]. The only variable separating an average African Grey or bonobo from being an Alex or Kanzi - from reaching, one could argue, Big-C - is opportunity. 
Human creativity researchers do not use the same arguments. When scholars study eminent creators such as Charles Darwin [21] or Pablo Picasso [19], it is with the hope that we might learn from how such eminent people created - not with the expectation that we are all potential geniuses with appropriate prompting. As a result, perhaps, we focus more on potential than on capacity. It is impossible to place all humans in a laboratory settings designed to maximize cognitive and creative capacity; as such, we devote more time to determining which specific techniques, environments, or behaviors may best lead to increased creativity. We are thus focused on improving an individual's potential, rather than outlining humankind's capacity for creativity.

As a result, human researchers tend to emphasize individual differences. Extensive studies are conducted on how creativity is predicted or related to such constructs as personality [14], motivation [24], intelligence [31], or self-beliefs [32]. Certain individual difference variables are considered necessary but not sufficient for creativity [35] and others are seen as being closely linked (such as openness to experience [13]). We can't manipulate every aspect of a human's environment (at least, not ethically), so we focus on the variables we can nurture - or, at least, the ones we can measure.

New animal research, however, is beginning to provide a basis for individual differences in behavior across several species. Much of the research on personality, intelligence and animal innovation is conducted on dolphins $[12 ; 28 ; 29 ; 40 ; 48]$ and primates $[11 ; 18$; 59]. There is even an intelligence test for primates, the Primate Cognition Test Battery $[9 ; 27 ; 57]$. Birds are have also shown individual differences in personality [17;26], and there are other species that have shown personality differences, including some unexpected ones such as mongooses [52] and spiders [20;30;39]. Could Alex's cognitive prowess be due in part to individual differences in personality or intelligence that separated him from other African Grey parrots? Perhaps Kanzi was able to learn to use language with such skill not simply because of an environment that provided ideal stimulation but because she was smarter or more open to experience than other bonobos.

Relationships have already been established between personality traits and animal behavior. For example, conciliatory behavior is positively correlated with the likelihood of switching social partners in primates [58]. Similarly, colonial living spiders who participate in communal prey capture demonstrate higher aggression levels [20].

Other studies also include elements related to creativity and innovation, such as neophobia. For example. a study of attention bias in parrots found that birds with high neuroticism scores took longer to get used to new people and had trouble attending to food when there was a perceived threat [10]. Hyenas who are more neophobic are worse solvers [6]. A recent particularly relevant study examined physiological states in birds and then measured their problem solving abilities. A specific set of physiological results - low corticosterone, high amounts of the antioxidant glutathione, and lower parasite load were associated with higher levels of problem solving [7].

There is much to learn from communication across disciplines. Interdisciplinary collaborations often instinctively understand that methods or broad theories are different. Yet taking a larger view and looking at the subtle nuances in underlying basic assumptions across fields is not an obvious step. As we have reviewed the literature on human and animal creativity, we have seen the core assumptions that lead human studies to emphasize 
the route from potential to ability and animal studies to focus on how capacity enables ability. Animal studies are already considering the role of individual differences and, as a result, how potential may interact with the capacity-ability connection. If this work continues to progress, we can gain a broad understanding of which individual differences are associated with higher creative and innovative performance. We may soon, perhaps, be able to explain exactly why your dog or cat is not quite as bright, curious, investigative, playful, or even creative as your neighbor's pets.

Meanwhile, it may be time for human creativity researchers to consider the idea of creative capacity. We so often use a Mozart or Einstein to illustrate why and how the average person is not a creative genius, or else to propose a false equivalence between a legendary work of art or science and the ordinary person's attempt at crafts that would only be of interest to family and close friends. Yet if a Da Vinci or Martin Luther King or W. B. Yeats were able to produce their creative brilliance with the same basic cortical structures, how terrible can it be to consider that all that separates any of us from such outcomes is the right combination of opportunity, effort, and luck?

\section{REFERENCES}

[1] Amabile T.M., Goldfarb P. \& Brackfield S.C. Social influences on creativity: Evaluation, coaction, and surveillance. Creativity Research Journal, 1990, vol. 3, pp. 6-21.

[2] Amabile T.M., Schatzel E.A., Moneta G.B. \& Kramer S.J. Leader behaviors and the work environment for creativity: Perceived leader support. The Leadership Quarterly, 2004, vol. 15, pp. 5-32.

[3] Baer J. \& Kaufman J.C. Bridging generality and specificity: The Amusement Park Theoretical (APT) Model of creativity. Roeper Review, 2005, vol. 27, pp. 158-163.

[4] Beghetto R.A. \& Kaufman J.C. Toward a broader conception of creativity: A case for "mini-c" creativity. Psychology of Aesthetics, Creativity, and the Arts, 2007, vol. 1, pp. 13-79.

[5] Beghetto R.A., Kaufman J.C. \& Baer J. Teaching for creativity in the common core classroom. New York: Teachers College Press, 2014.

[6] Benson-Amram S. \& Holekamp K.E. Innovative problem solving by wild spotted hyenas. Proceedings. Biological Sciences / The Royal Society, 2012. vol. 279, pp. 4087-95.

[7] Bókony V., Lendvai Á.Z., Vágási C.I., Pătraş L., Pap P.L., Németh J., ... Liker A. Necessity or capacity? Physiological state predicts problem-solving performance in house sparrows. Behavioral Ecology, (2014), vol. 25, pp. 124-135.

[8] Burghardt G. A brief glimpse at the long evolutionary history of play. Animal Behavior and Cognition, 2014, vol. 1, pp. 90-98.

[9] Chamove A.S., Eysenck H.J. \& Harlow H.F. Personality in monkeys: Factor analyses of Rhesus social behavior. Quarterly Journal of Experimental Psychology, 1972, vol. 24, pp. 496-504.

[10] Cussen V.A. \& Mench J.A. Personality predicts cognitive bias in captive psittacines, Amazona amazonica. Animal Behaviour, 2014, vol. 89, pp. 123-130.

[11] Dingemanse N.J. \& R ale D. Natural selection and animal personality. Behaviour, 2005, vol. 142, pp. 1159-1184.

[12] Eskelinen H.C., Winship K.A, \& Borger-turner J.L. Sex, age, and individual differences in Bottlenose Dolphins (Tursiops truncatus) in response to environmental enrichment, Animal Behavior and Cognition, 2015, vol. 2, pp. 241-253.

[13] Feist G.J. A meta-analysis of personality in scientific and artistic creativity. Personality and Social Psychology Review, 1998, vol. 2, pp. 290-309.

[14] Feist G.J. The function of personality in creativity: The nature and nurture of the creative personality. In J.C. Kaufman \& R.J. Sternberg (Eds.), The Cambridge handbook of creativity. New York, NY, US: Cambridge University Press, 2010, pp. 113-130. 
[15] Forgeard M.J.C. \& Kaufman J.C. Who cares about imagination, creativity, and innovation, and why? A review. Psychology of Aesthetics, Creativity, and the Arts, 2016, vol. 10, pp. 250-269.

[16] Forgeard M.J.C. \& Mecklenburg A.C. The two dimensions of motivation and a reciprocal model of the creative process. Review of General Psychology, 2013, vol. 17, pp. 255-266.

[17] Garamszegi L.Z., Eens M., Török J. \& Tregenza T. Birds reveal their personality when singing. PLoS ONE, 2008, vol. 3, e2647.

[18] Gosling S.D. From mice to men: What can we learn about personality from animal research? Psychological Bulletin, 2001, vol. 127, pp. 45-86.

[19] Gardner H. Creating minds. New York: Basic Books, 1993.

[20] Grinsted L., Pruitt J.N., Settepani V. \& Bilde T. Individual personalities shape task differentiation in a social spider. Proceedings. Biological Sciences / The Royal Society, 2013, vol. 280, pp. 20131407.

[21] Gruber H.E. \& Wallace D.B. Creative work: The case of Charles Darwin. American Psychologist, 2001, vol. 56, pp. 346-349.

[22] Haldane J.B.S. The cost of natural selection. Journal of Genetics, 1957, vol. 55, pp. 511-524.

[23] Hegarty C.B. \& Plucker J.A. Self-expression in creative leisure. International Journal of Creativity and Problem Solving, 2012, vol. 22, pp. 63-78.

[24] Hennessey B.A. If I were Secretary of Education: A focus on intrinsic motivation and creativity in the classroom. Psychology of Aesthetics, Creativity, and the Arts, 2015, vol. 9, pp. 187-192.

[25] Hennessey B.A. \& Amabile T.M. Creativity. Annual Review of Psychology, 2010, vol. 61, pp. 569598.

[26] Hergovich A., Mauerer I. \& Riemer V. Exotic animal companions and the personality of their owners. Anthrozoos: A Multidisciplinary Journal of The Interactions of People \& Animals, 2011, vol. 24, pp. 317-327

[27] Herrmann E. \& Call J. Are there geniuses among the apes? Philosophical Transactions of the Royal Society of London. Series B, Biological Sciences, 2012, vol. 367, pp. 2753-61.

[28] Highfill L.E. \& Kuczaj S.A. Do bottlenose dolphins (Tursiops truncatus) have distinct and stable personalities? Aquatic Mammals, 2007, vol. 33, pp. 380-389.

[29] Highfill L.E. \& Kuczaj S.A. How studies of wild and aptive dolphins contribute to our understanding of individual differences and personality. International Journal of Comparative Psychology, 2010, vol. 23, pp. 269-277.

[30] Holbrook C.T., Wright C.M. \& Pruitt J.N. Individual differences in personality and behavioural plasticity facilitate division of labour in social spider colonies. Animal Behaviour, 2014, vol. 97, pp. 177-183.

[31] Jauk E., Benedek M., Dunst B. \& Neubauer A.C. The relationship between intelligence and creativity: new support for the threshold hypothesis by means of empirical breakpoint detection. Intelligence, 2013, vol. 41, pp. 212-221.

[32] Karwowski M. \& Lebuda I. The big five, the huge two, and creative self-beliefs: A meta-analysis. Psychology of Aesthetics, Creativity, and The Arts, 2016, vol. 10, pp. 214-232.

[33] Kaufman A.B., Butt A.B., Colbert-White E.N. \& Kaufman J.C. Towards a neurobiological model of creativity in nonhuman animals. Journal of Comparative Psychology, 2011, vol. 125, pp. 255272.

[34] Kaufman J.C. Creativity 101 (2 ${ }^{\text {nd }}$ Edition). New York: Springer, 2016.

[35] Kaufman J.C. \& Baer J. The Amusement Park Theoretical (APT) Model of creativity. Korean Journal of Thinking and Problem Solving, 2004, vol. 14, pp. 15-25.

[36] Kaufman J.C. \& Beghetto R.A. Beyond big and little: The Four C Model of Creativity. Review of General Psychology, 2009, vol. 13, pp. 1-12.

[37] Kaufman J.C. \& Kaufman A.B. Applying a creativity framework to animal cognition. New Ideas in Psychology, 2004, vol. 22, pp. 143-155.

[38] Kawai M. Newly-acquired pre-cultural behavior of the natural troop of Japanese monkeys on Koshima islet . Primates, 1965, vol. 6, pp. 1-30.

[39] Kralj-Fi er S. \& Schneider J.M. Individual behavioural consistency and plasticity in an urban spider. Animal Behaviour, 2012, vol. 84, pp. 197-204. 
[40] Kuczaj S.A., Highfill L. \& Byerly H. The importance of considering context in the assessment of personality characteristics: Evidence from ratings of dolphin personality. International Journal of Comparative Psychology, 2012, vol. 25, pp. 309-329.

[41] Kummer H. \& Goodall J. Conditions of Innovative Behaviour in Primates. Philosophical Transactions of the Royal Society of London. Series B, Biological Sciences, 1985, vol. 308, pp. 203214.

[42] Lloyd E. Kanzi, evolution, and language. Biology \& Philosophy, 2004, vol. 19, pp. 577-588.

[43] Maslow A. Motivation and personality. New York, NY: Harper, 1954.

[44] Pepperberg I.M. The Alex studies: Cognitive and communicative abilities of grey parrots. Cambridge, MA: Harvard University Press, 1999.

[45] Pepperberg I.M. Cognitive and communicative abilities of Grey parrots. Applied Animal Behaviour Science, 2006, vol. 100, pp. 77-86.

[46] Pepperberg I.M. Grey parrots do not always "parrot": the roles of imitation and phonological awareness in the creation of new labels from existing vocalizations. Language Sciences, 2007, vol. 29, pp. 1-13.

[47] Pepperberg I.M. Further evidence for addition and numerical competence by a Grey parrot (Psittacus erithacus). Animal Cognition, 2012, 711-717.

[48] Ramsey G., Bastian M.L. \& van Schaik C. Animal innovation defined and operationalized. The Behavioral and Brain Sciences, 2007, vol. 30, pp. 393-407.

[49] Reader S.M. \& Laland K.N. Animal innovation: An introduction. In S.M. Reader \& K.N. Laland (Eds.), Animal Innovation. Oxford, UK: Oxford University Press, 2003, pp. 3-38.

[50] Russ S.W. \& Fiorelli J.A. Developmental approaches to creativity. In J.C. Kaufman \& R.J. Sternberg (Eds.), Cambridge handbook of creativity. New York: Cambridge University Press, 2010, pp. 233249.

[51] Russ S.W. \& Wallace C.E. Pretend play and creative processes. American Journal of Play, 2013, vol. 6, pp. 136-148.

[52] Sanderson J.L., Stott I., Young A.J., Vitikainen E.I.K., Hodge S.J. \& Cant M.A. The origins of consistent individual differences in cooperation in wild banded mongooses, Mungos mungo. Animal Behaviour, 2015, vol. 107, pp. 193-200.

[53] Savage-Rumbaugh E.S. \& Lewin R. Kanzi: The ape at the brink of the human mind. New York: Wiley and Sons, 1994.

[54] Simonton D.K. Genius 101. New York: Springer, 2009.

[55] Torrance E.P. Education and the creative potential. Minneapolis, MN: University of Minnesota Press, 1963.

[56] Triana E. \& Pasnak R. Object permanence in cats and dogs. Learning \& Behavior, 1981, vol. 9, pp. 135-139.

[57] Vonk J. \& Povinelli D. Individual differences in long-term cognitive testing in a group of captive chimpanzees. International Journal of Comparative Psychology, 2011, vol. 24, pp. 137-167.

[58] Webb C.E., Franks B., Romero T., Higgins E.T. \& de Waal F.B.M. Individual differences in chimpanzee reconciliation relate to social switching behaviour. Animal Behaviour, 2014, vol. 90, pp. 57-63.

[59] Weiss A., Staes N., Pereboom J.J.M., Inoue-Murayama M., Stevens J.M.G. \& Eens M. Personality in bonobos. Psychological Science, 2015, vol. 26, pp. 1430-1439.

Received 15 September 2016

Accepted 24 October 2016 


\title{
ЗАДАТКИ, ВОЗМОЖНОСТИ И СПОСОБНОСТИ: ИНТЕГРАЦИЯ ПОДХОДОВ К ИССЛЕДОВАНИЮ ТВОРЧЕСКИХ ПРОЦЕССОВ У ЧЕЛОВЕКА И ЖИВОТНЫХ
}

\author{
Д.К. Кауфман \\ Коннектикутский университет \\ 2131 Hillside Road, Storrs, CT 06269-3007, USA \\ Э.Б. Кауфман \\ Коннектикутский университет \\ 1084 Shennecossett Rd., Groton, CT 06340, USA
}

\begin{abstract}
При всех различиях в изучении творческих и инновационных процессов у животных и человека существует и определенное сходство, которое можно лучше понять при интеграции обоих подходов. Оба подхода направлены на изучение творческих способностей, но исследователи животных предпочитают концепцию творческих задатков, а исследователи человека творческого потенциала. В статье рассмотрены следствия, вытекающие из различий в исследовательских подходах, а также то, чем данные подходы могут обогатить друг друга.

На основании обзора литературы по проблеме исследования творческих процессов у человека и животных выявлены основные положения, которые позволяют исследователям человека показать путь от возможностей (потенциала) к способностям, а исследователям животных - от задатков к способностям. Исследователи животных уже рассматривают индивидуальные различия между ними и, как результат, показывают, как возможности могут опосредовать связь между задатками и способностями. Если работа в этом направлении будет продолжена, то может быть выявлено то, каким образом индивидуальные различия связаны с высокими творческими и инновационными проявлениями.
\end{abstract}

Ключевые слова: творчество, творческие процессы у животных, творческие задатки, творческий потенциал, творческие способности, творческий гений

Поступила в редакцию 15.09.2016

Принята к печати 23.10.2016 